\title{
Insider Trading: Hayek, Virtual Markets, and the Dog that Did Not Bark
}

\author{
HENRY G. MANNE *
}

\begin{abstract}
"How is the betting?"
"Well, that is the curious part of it. You could have got fifteen to one yesterday, but the price has become shorter and shorter, until you can hardly get three to one now."

"Hum!" said Holmes. "Somebody knows something, that is clear!"

Inspector Gregory: "Is there any other point to which you would wish to draw my attention?"

Holmes: "To the curious incident of the dog in the night-time."

"The dog did nothing in the nighttime"

"That was the curious incident," remarked Sherlock Holmes.

From The Adventure of Silver Blaze by Arthur Conan Doyle
\end{abstract}

This Essay briefly reexamines the great debates on the role of insider trading in the corporate system from the perspectives of efficiency of capital markets, harm to individual investors, and executive compensation. The focus is on the mystery of why trading by all kinds of insiders as well as knowledgeable outsiders was studiously ignored by the business and investment communities before the advent of insider trading regulation. It is hardly conceivable that officers, directors, and controlling shareholders would have remained totally silent in the face of widespread insider trading if they had seen the practice as being harmful to the company, to themselves, or to investors. By analogy with the famous article by Friedrich Hayek, The Use of Knowledge in Society, this Essay considers the problem of obtaining necessary information for managers of large corporate enterprises. The suggested analytical framework views the share price, sensitively impacted by informed trading, as a mechanism for timely transmission of valuable information to top managers and large shareholders. Informed trading in the stock market is also compared to "prediction" or "virtual" markets currently used by corporations and policymakers.

\section{PART I - BACKGROUND}

It is almost 40 years since the publication of my book, Insider Trading and the Stock Market, ${ }^{1}$ and the topic still has the ability to engender heated argument as well as

\footnotetext{
*Dean Emeritus and University Professor Emeritus, George Mason University School of Law. Copyright (C) 2005, Henry G. Manne. I am grateful to Stephen M. Bainbridge, George Benston, William Carney, Enrico Colombatto, Stanislav Dolgopolov, William Klein, Geoffrey Manne, Sam Peltzman, and Larry Ribstein for helpful suggestions and discussions.
} 
seemingly unending efforts at analytical explication. ${ }^{2}$ I apologize at the outset for continuing the debate, especially since I myself thought that it had about run its course. Nonetheless, the topic refuses to die, and it continues to stimulate new hypotheses, one of which is about to be offered.

This taxing of the intellectual tolerance of critics of insider trading may have a redeeming feature for many. In the process of developing this new idea, I have had to reexamine and substantially modify perhaps the most vigorously criticized claim I made for the positive benefits of unregulated insider trading. That was the notion that insider trading can be used as an important component of executive compensation. I hope that I am about to offer a much stronger substitute argument.

Fundamentally, my book made only three basic economic arguments. ${ }^{3}$ One was that the practice of insider trading did no significant harm to long-term investors. The other two were claims of positive benefits from the practice, one, the compensation argument, and the other, the idea that insider trading contributed importantly to the efficiency of stock market pricing.

By and large the idea that there is no direct harm from the practice has held up very well, especially the point that no real damage is caused to an investor who engages anonymously on an exchange in a trade with an insider on the other side of the transaction. However, one "harm" argument of feasible merit" has dominated the academic literature for some time. This is the so-called "adverse selection" argument.

\footnotetext{
${ }^{1}$ HenRy G. MANNE, INSIDER TRADING AND THE StOCK MARKet (1966).

${ }^{2}$ For an excellent though but already somewhat dated bibliography, see Stephen M. Bainbridge, Insider Trading, in III ENCYCLOPEDIA OF LAW AND ECONOMICS 772, 798-812 (Boudewijn Bouckaert \& Gerrit De Geest eds., 2000). For the most comprehensive treatise, see WILLIAM K.S. WANG \& MARC I. STEINBERG, INSIDER TRADING (1996 \& Supp. 2002).

${ }^{3}$ This discussion leaves aside such tangential but important issues as the enforceability of insider trading laws and public choice aspects of the subject, as well as such tangential but economically irrelevant notions as the fairness of the practice.

${ }^{4}$ I do not consider the SEC's "official" line on insider trading, that it destroys the confidence of investors and thus lessens both liquidity and investment, to have serious merit. Apart from being a nearly unfalsifiable proposition, it is devoid of the scantest economic or empirical content. It has, however, been
} 
Basically the argument is that, since specialists on the floor of stock exchanges (or other market makers) systematically lose money when insiders are trading, they will expand their bid-ask spread in order to cover this greater cost of doing business. In this fashion, it is argued, they pass along the cost of insiders' trading to all outside investors with whom they deal, the so-called "insider trading tax.,"5

The first part of this argument is really just a variant of the idea in my book that shortterm traders would indeed frequently lose to insiders ${ }^{6}$ (a warning against using the stock market as a gambling casino). I suggested that long-term investors ${ }^{7}$ had little to worry about quantitatively because of insider trading, and the same thing remains true regardless of the existence of some adverse selection. Furthermore, there is considerable evidence that the harm to market makers exists more in the theoretical world of finance literature than it does in the actual play of the market. Though the argument is theoretically feasible, it seems to be practically irrelevant in the real world. ${ }^{8}$

Of the two arguments that I offered for positive benefits from insider trading, the argument for a strong positive relationship between market efficiency and insider trading has proved to be very robust. I missed the very important and related advantage pointed out by Harold Demsetz that access to valuable trading information may allow controlling shareholders to be compensated for the additional risk they assumed by not being well

enormously important in the propaganda campaign the SEC has waged for years to demonize insider trading.

${ }^{5}$ Walter Bagehot (pseud. for Jack L. Treynor), The Only Game in Town, Fin. ANALYSTS J., Mar.-Apr. 1971, at 12; Thomas E. Copeland \& Dan Galai, Information Effects on the Bid-Ask Spread, 38 J. FIN. 1457 (1983); Lawrence R. Glosten \& Paul R. Milgrom, Bid, Ask and Transaction Prices in a Specialist Market with Heterogeneously Informed Traders, 14 J. FIN. ECON. 71 (1985).

${ }^{6}$ Perhaps in some sense long-term traders lose as well, but quantitatively that is insignificant as compared to shork termers, and even then one must look at various offsetting advantages. See also Henry G. Manne, In Defense of Insider Trading, HARV. Bus. REV., Nov.-Dec. 1966, at 113, 114-15.

${ }^{7}$ This refers to investors whose trades represent fundamentally a rebalancing of diversified portfolios to reflect changed circumstances or altered weightings in a previously correctly balanced portfolio.

${ }^{8}$ See Stanislav Dolgopolov, Insider Trading and the Bid-Ask Spread: A Critical Evaluation of Adverse Selection in Market Making, 33 CAP. U. L. REV. 83 (2004). One of the most telling criticisms of the adverse selection argument is that liquidity providers themselves - including the NYSE specialists and the NASDAQ dealers (but with the exception of liquidity providers in options markets) - are not generally concerned about the presence of insiders in stocks in which they make a market. Id. at 108-10, 136-144. 
diversified. ${ }^{9}$ This is an especially important factor in corporate governance, since, without a controlling shareholder, agency costs in large corporations, normally dealt with through an exogenous market for corporate control, will be much higher.

There is almost no disagreement that insider trading does always push the price of a stock in the correct direction. ${ }^{10}$ This is not to gainsay that there are also other mechanisms that play a significant role in stock pricing, such as the explicit public disclosure of new information, sanctioned transmittal of information to financial analysts, and the so-called "derivative" trading that occurs after some form of market "signaling."

\footnotetext{
${ }^{9}$ See Harold Demsetz, Corporate Control, Insider Trading and Rates of Return, 76 AM. ECON. REv. (PAPERS \& PROC.) 313 (1986). It is appropriate to note that controlling shareholders perform a valuable management-monitoring function not shouldered by others shareholders, whose incentive would be to free ride (the ultimate "separation" problem). Demsetz, however, may have overlooked the extent to which a control block of shares presents agency cost problems of its own, since there are other devices besides inside information by which a controlling shareholder may transfer wealth from minority shareholders.

${ }^{10}$ For empirical research arguing that insider trading quickly incorporates the impact of nonpublic information into the market price, see Ji-Chai Lin \& Michael S. Rozeff, The Speed of Adjustment of Prices to Private Information: Empirical Tests, 18 J. Fin. ReS. 143 (1995); Lisa K. Meulbroek, An Empirical Analysis of Illegal Insider Trading, 47 J. FIN. 1661 (1992). The only significant arguments are with the extent and timeliness of a price effect from insider trading. See Sugato Chakravarty \& John J. McConnell, Does Insider Trading Really Move Stock Prices?, 34 J. Fin. \& QuantiTATIVE ANALYsIS 191 (1999) (offering empirical evidence for the proposition that informed trading by insiders has the same price impact as uninformed trading by outsiders); James D. Cox, Insider Trading and Contracting: A Critical Response to the "Chicago School," 1986 DUKE L.J. 628, 646 (arguing that insider trading is a "noisy" device for communicating the stock value). Research with "laboratory" experiments suggests that inside information is rapidly assimilated into market price and that this may occur even with very few insiders participating in the market, a finding particularly relevant here. See, e.g., Martin Barner et al., On the Microstructure of Price Determination and Information Aggregation with Sequential and Asymmetric Information Arrival in an Experimental Asset Market, 1 ANNALS FIN. 1 (2005); Daniel Friedman et al., The Informational Efficiency of Experimental Asset Markets, 92 J. POL. ECON. 349 (1984); Charles R. Plott \& Shyam Sunder, Efficiency of Experimental Security Markets with Insider Information: An Application of RationalExpectations Models, 90 J. PoL. ECON. 663 (1982). But see Vernon L. Smith et al., Bubbles, Crashes, and Endogenous Expectations in Experimental Spot Asset Markets, 56 ECONOMETRICA 1119 (1988).

${ }^{11}$ The standard reference for this discussion is Ronald J. Gilson \& Rainier H. Kraakman, The Mechanisms of Market Efficiency, 70 VA. L. REV. 549 (1984). Without getting into too much detail, there are two significant weaknesses in Gilson and Kraakman's implicit effort to minimize the role of insider trading in this process. One is their failure to reckon with the price influence of insiders' refraining from buying or selling when they have undisclosed information. The other is a certain ambiguity in the concept of "derivative" trading, since it would seem that most of this trading must actually follow actual informed trading, including especially insiders' trades. Thus they implicitly underestimated the relative influence of insider trading in making the stock market efficient. That particular ambiguity is gone in the recent update of their piece, Ronald J. Gilson \& Reinier Kraakman, The Mechanisms of Market Efficiency Twenty Years Later: The Hindsight Bias, 28 J. CORP. L. 715 (2003), but there is still no emphasis put on this fairly obvious feature of market efficiency. This article gives more significance than is due to the impact on market efficiency of behavioral finance and the cognitive bias it posits with noise trading (as if all noise trading was not always seen as a kind of economic irrationality). And they give far less significance than is
} 
has developed examining the relative impact of these various mechanisms on stock market pricing, but it is fair to say that none of this has seriously damaged the argument of the stock-pricing benefit of insider trading. This is not the right time or place to review that literature, and for present purposes we merely need to understand that insider trading does have the price vector claimed for it, even though this mechanism alone may play less than an exclusive role in making stock market pricing as efficient as it is. ${ }^{12}$ The crucial point for present purposes is that, even if only on a few occasions and either by itself or in tandem with other forces, insider trading may be sufficient to move the price of a company's stock.

My second "positive" argument for insider trading, that it could perform well as a part of an executive compensation package, has been the more forcefully attacked, ${ }^{13}$ and it is perhaps less robust than I and other proponents ${ }^{14}$ had originally assumed. The insidertrading compensation argument has become especially relevant in recent years, ${ }^{15}$ as a great debate has swirled through business, regulatory, and legal circles about the proper way to compensate corporate executives. Much of this discussion has focused recently on

due to the market inefficiencies created by various bits of securities regulation, though they do emphasize the special problem of the federal securities law's bias against short selling. Unfortunately that is not the only or even the most significant interference with market efficiency to be found in our complex securities regulations.

${ }^{12}$ An argument could be made, of course, that all price changes result from new information that someone has traded on profitably. The impact of explicit disclosure is often to confirm that the price reached in other ways is correct. But this argument still allows explicit disclosure an important role in making stock market pricing efficient.

${ }^{13}$ StePHEN M. BAINBRidge, CoRporation LAW AND ECONOMics 593 (2002) (insider trading creates the incentive for managers to disclose information prematurely ); ROBERT CHARLES CLARK, CORPORATE LAW 273-74 (1986) (insider trading allows managers to determine their own compensation packages and undo formal compensation agreements); Cox, supra note 10, at 651-52 (insider trading is likely to increase managers' tolerance of bad news); Frank H. Easterbrook, Insider Trading, Secret Agents, Evidentiary Privileges, and the Production of Information, 1981 SUP. CT. REV. 309, 332 (insider trading may induce managers to accept excessively risky projects; insider trading as managerial compensation may be inefficient, as risk-averse managers would value trading profits differently than risk-neutral shareholders); Robert J. Haft, The Effect of Insider Trading Rules on the Internal Efficiency of the Large Corporation, 80 MiCH. L. REV. 1051 (1982) (insider trading is likely to interfere with the flow of information within the firm); Roy A. Schotland, Unsafe at Any Price: A Reply to Manne, Insider Trading and the Stock Market, 53 VA. L. REV. 1425, 1448-50 (1967) (insider trading is likely to induce managers to delay disclosure and participate in market manipulation).

${ }^{14}$ See especially Dennis W. Carlton \& Daniel R. Fischel, The Regulation of Insider Trading, 35 STAN. L. REV. 857 (1983).

${ }^{15}$ See Henry G. Manne, Options? Nah. Try Insider Trading., WALL ST. J., Aug. 2, 2002, at A8. 
stock options, since they were so heavily relied upon to compensate employees of the firms that figured heavily in the market collapse of the early 2000's. The focus on stock options in turn logically implicates the insider trading compensation argument, since the two are undoubtedly the closest substitutes in the compensation arena.

A stock option offers the same incentive to employees to work efficiently that would be provided by ownership of an appropriate number of shares, however obtained, but leveraged by non-recourse, interest-free debt. The indirect incentive effects of this leveraging are very difficult to value for corporate accounting purposes or, for that matter, for the purpose of determining the value of the option to an employee. ${ }^{16}$ Thus, even though there are a forward look and a leverage feature to options that cannot be obtained, say, with bonuses, there are still real problems with determining the exact incentive effect of stock option grants. ${ }^{17}$

After the option is exercised, and to the extent the employee holds on to the shares, the executive becomes a (larger) shareholder. Stock ownership obviously motivates a manager to maximize share price, especially if the shares represent a substantial part of the employee's portfolio. However, since the shares will represent only a tiny fraction of the company's outstanding shares, for familiar free-rider reasons, the induced incentive for risky choices may still fall short of what would be dictated by the interest of all shareholders. In other words, as a number of studies suggest, stock options at best offer

\footnotetext{
${ }^{16}$ The corporation's valuation of the same option may be quite different from that of the employee, as the debate about the FASB's recent requirement that the options be valued as an expense on the corporate books well attests. See Fin. ACCT. Standards BD., StATEMENT OF FinanCial AcCounting STANDARdS No. 123, SHARE-BASED PAYMENT (rev. Dec. 2004), available at http://www.fasb.org/pdf/fas123r.pdf (last visited ___. See also Brian J. Hall \& Kevin J. Murphy, Stock Options for Undiversified Executives, 33 J. ACCT. \& ECON. 3, 5 (2002) (arguing that the option's cost to the company "often significantly exceeds the value of the option from the perspective of a risk-averse, undiversified executive who can neither sell the option nor hedge against its risk").

${ }^{17}$ Michael C. Jensen \& Kevin J. Murphy, Remuneration: Where We Have Been, How We Got to Here, What Are the Problems, ANd How to Fix Them (Harvard Bus. Sch., NOM Research Paper No. 04-28, 2004), available at http://www.ssrn.com/Abstract=561305 (last visited __); Lucian Arye Bebchuk et al., Managerial Power and Rent Extraction in the Design of Executive Compensation, 69 U. CHI. L. Rev. 751 (2002); Saul Levmore, Puzzling Stock Options and Compensation Norms, 149 U. PA. L. REV. 1901 (2001); David Yermack, Do Corporations Award CEO Stock Options Effectively?, 39 J. FIN. ECON. 237 (1995); David Yermack, Good Timing: CEO Stock Option Awards and Company News Announcements, 52 J. FIN. 449 (1997).
} 
no greater incentive than would an appropriate, but difficult to determine, number of shares held by the manager, however acquired, and leveraged by debt. ${ }^{18}$ At worst they may provide real adverse incentives. ${ }^{19}$

When stock options are the primary device used to encourage risky decisions by managers, and to the extent that insider trading is effectively, or even substantially, prevented, the financial focus of corporate officials will necessarily be on accounting information, since the real world events underlying those entries cannot be traded on directly as they occur. The legal flow of information to the market will be via formal, SEC-sanctioned disclosures, including press releases, quarterly reports, 10-K's, and duly publicized conferences with financial analysts. Since future expected profits cannot be shown on the books, and trading on the underlying information is not allowed, the urge to make the accounting picture look better in order to have it conform to management's current view of the company's prospects - biased or not - may become irresistible. It is at least arguable that this constituted part of the underlying pressure for what occurred at Enron and various telecommunications companies. ${ }^{20}$

Insider trading on the other hand does not have these disadvantages. It in effect allows insiders meticulously to craft their own reward for innovations almost as soon as they occur and to trade without harm to any investors. ${ }^{21}$ The incentive is immediate and

${ }^{18}$ It is not surprising that the empirical studies of the incentive effects of options show a mixed bag. This device is arguably most useful in companies with executives who might have difficulty borrowing sufficient money to leverage their own purchases of their companies' shares, as may have been particularly the case with many high-tech start-up companies in recent years.

${ }^{19}$ See Michael C. Jensen, Stock Options Reward Management for Destroying Value and What TO Do AвоUT IT (Harvard Bus. Sch., NOM Research Paper No. 01-27, 2001); available at http://www.ssrn.com/Abstract=480401 (last visited __).

${ }^{20}$ This is not an excuse for illegal and fraudulent behavior, but it does reveal a type of unanticipated consequence of securities regulation that rarely figures in the calculus of whether that regulation is desirable or not. One can compare this notion to what Michael Jensen terms the problem of "overvalued equity." See Michael C. Jensen, The Agency Costs of Overvalued Equity and the Current State of Corporate Finance, 10 EUR. FIN. MGMT. 549 (2004).

${ }^{21}$ A clear statement on this proposition was provided by Carlton and Fischel:

Insider trading may present a solution to [the] cost-of-renegotiation dilemma. The unique advantage of insider trading is that it allows a manager to alter his compensation package in light of new knowledge, thereby avoiding continual renegotiation. The manager . . . in effect "renegotiates" each time he trades. This in turn increases the manager's incentive to 
precise and is never confounded with stock price changes that are not of the managers' making.

If insider trading were legal and used to replace stock options, there would be no "tragedies" of employees being left high and dry with options way out of the money. There would be no loss of reward when an innovation merely resulted in a reduction of an expected loss. There would be no unearned gain because a company's stock appreciates in line with a market or industry rise. There would be no disappointments about the number of shares optioned or granted to particular employees. There would be none of this absurd business of renegotiating the option plan every time the stock takes a nosedive. And there would be no peculiar problems of accounting, since there would be no reason to put the right of employees to trade on undisclosed information on the company's balance sheet at all: such trading would be entirely extraneous to the company's accounts.

The SEC's notoriously ineffective but highly publicized and politicized efforts to enforce insider trading laws have merely shifted the identity of the people who may trade first on undisclosed information. ${ }^{22}$ In the process they have perhaps prevented the development of an innovative and useful compensation device and unduly encouraged a problematic second best.

Having said that, however, it must be recognized that insider trading cannot be a perfect form of incentive compensation. While many of the criticisms of the practice are vacuous

acquire and develop valuable information in the first place (as well as to invest in firmspecific human capital).

Carlton \& Fischel, supra note 14, at 870-71. The point about "no harm to investors" does not mean that short term traders (really gamblers) or market makers trading against insiders will not lose money. They will, though they will only lose negligibly more than they would if insiders were not in the market but the price level change (or the release time of new information) was the same.

${ }_{22}^{2}$ David D. Haddock \& Jonathan R. Macey, Regulation on Demand: A Private Interest Model, with an Application to Insider Trading Regulation, 30 J.L. \& ECON. 311 (1987) (arguing that the existence of insider trading regulation benefited "market professionals" in the securities industry). Compare this to the problem addressed by Regulation FD which prohibited the practice of selective disclosure by issuers to 
or even tendentious, there are significant problems with the scheme which many of my critics hastened to elaborate. Valuable information will undoubtedly get into the hands of individuals inside and outside the company who in no sense should be compensated, usually because they will have done nothing to produce the valuable new information. ${ }^{23}$ Another problem is that the value of the information cannot be metered to the value of the contribution of a particular individual. And, as was also pointed out, the value of new information will in many cases be a function of the financial ability of someone to trade on the information or of their ability to evaluate new knowledge. ${ }^{24}$

Perhaps the most common objection to insider trading as compensation is that it cannot be metered in advance as part of a compensation plan. ${ }^{25}$ It is in its very nature a kind of all or nothing proposition, since efforts by a given corporation to police its rules about who can trade, and to what extent, will necessarily involve the company in exactly the kind of post hoc compensation calculations that the practice is argued by its supporters to avoid. ${ }^{26}$ It is not too surprising then that, even in the heyday of insider trading in the

securities analysts and large shareholders. Selective Disclosure and Insider Trading, Exchange Act Release No. 43,154, 65 Fed. Reg. 51,716 (Aug. 15, 2000).

${ }^{23}$ This argument, like the ones to follow, necessarily reflects only a partial equilibrium conclusion. There are many other positive points that must be included in a general equilibrium solution.

${ }^{24}$ Morris Mendelson, The Economics of Insider Trading Reconsidered, 117 U. PA. L. REV. 470, 488 (1969); Schotland, supra note 13, at 1455.

${ }^{25}$ This criticism may not be quite a forceful as it first appears. If one would grant the distinction I referred to in my book between managers and entrepreneurs, there is still much vitality left in the information-ascompensation argument. A problem in this connection with this otherwise valuable economic concept of the entrepreneur, however, is that it allows little useful application since one can never know ahead of time who in a large company will be the real entrepreneur. Thus insider trading has to be allowed either for all or for none; there is no middle ground. While, for a variety of reasons, I would still conclude that nonregulation is the best solution, I would not deny some force to the argument of those who came down on the other side of the compensation argument.

${ }^{26}$ The difficulty of individual company's policing insider trading (assuming that the company thought there was something harmful in the practice) was one basis for Judge Easterbrook's conclusion that the practice should be outlawed and policed (efficiently? and at what other costs?) by public authorities, something of a non-sequitur, since there is no evidence that any company ever actually faced this problem. See Frank H. Easterbrook, Insider Trading as an Agency Problem, in PRINCIPALS AND AGENTS: THE STRUCTURE OF BUSINESS 81, $93-95$ (John W. Pratt \& Richard. Zeckhauser eds., 1985). 
United States before $1968,{ }^{27}$ no company ever announced that certain executives, but not other employees, would be allowed to engage in the practice. ${ }^{28}$

Indeed it is not surprising that there is no evidence that any company ever tried to develop insider trading as an explicit and integral part of an optimal compensation package. On the other hand, our understanding of corporate inaction on insider trading as compensation tells us nothing about the far more startling fact that very few companies in the United States, prior to the SEC's involvement with the subject, seemed to have had a rule against insider trading. ${ }^{29}$ And, perhaps even more surprising, there is no significant or convincing evidence of which I am aware that any company or its spokespersons or large shareholders ever pushed for public regulation of insider trading when it was surely widely known that it was going on. ${ }^{30}$ The pre-Texas Gulf Sulphur business community was perhaps understandably silent about insider trading as a compensation device, since it probably was not really a feasible practice, but they were also - far more mysteriously silent about any problems they might have found generally with the very common practice of insider trading. That is precisely the mystery which can now be solved with a little help from the "dog that did not bark."

\section{PART II - THE MYSTERY}

It is hardly conceivable that officers, directors and controlling shareholders, would have remained totally silent in the face of widespread insider trading if they had seen the

\footnotetext{
${ }^{27}$ The first significant judicial holding that insider trading was generally a violation of Rule 10b-5 was SEC v. Texas Gulf Sulphur Co., 401 F.2d 833 (2d Cir. 1968) (en banc), cert. denied, 404 U.S. 1005 (1971). However, SEC's warnings certainly appeared earlier. See In re Cady, Roberts \& Co., 40 S.E.C. 907 (1961).

${ }^{28}$ I have for years labored - and pressured students - to come up with the outline of a workable compensation plan utilizing insider trading. But, given the constraints implied by the discussion in the text, this has proved to be a fruitless task.

${ }^{29}$ See Adolf A. Berle, Jr. \& Gardiner C. Means, The Modern Corporation and Private Property 327 (1932) ("It is known that certain companies, usually under the dominance of some strong individuals, decline to permit anyone . . whether as director or employee to conduct speculative operations in the corporate stock. On the other hand, it is certain that this is not the general practice ....")

${ }^{30}$ An interesting bit of support for the notion that there was no concern about the "evils" of insider trading comes from the fact that, as late as 1939, the New York Stock Exchange and other leading exchanges, proposed that Section 16(b) of the Securities and Exchange Act of 1934, the only provision thought to
} 
practice as being harmful to the company, to themselves, or to investors. And it is equally inconceivable that they would not have recognized some harm if it existed. Insider trading must have been as much a way of life in the U.S. securities markets prior to the 1960's as it is known to have been at a much later date in Japan and other countries. Its existence was so common and taken for granted that there was no need for empirical or even anecdotal evidence for the practice. ${ }^{31}$

And yet no one of significance in the business world was ever heard to complain about the practice or much less to declare it to be the moral equivalent of murder or rape in the commercial arena. ${ }^{32}$ This silence is a mystery that has not been noticed or addressed by modern writers - until now. What can possibly explain this puzzling behavior? Perhaps the practice was thought, as it is today, to be so heinous that no one wanted even to relate even modestly to insider trading, be repealed. Text of Exchanges' Proposals to SEC, WALL ST. J., Mar. 15, 1939, at 11. But see infra note 32.

${ }^{31}$ Classic histories include Henry Clews, FifTy Years IN WAll Street (1908) and Edwin LefÈvRe, REMINISCENCES OF A STOCK OPERATOR (1923). For evidence of contemporary practices in Japan and elsewhere, see Utpal Bhattacharya \& Hazem Daouk, The World Price of Insider Trading, 57 J. Fin. 75 (2002); Jan Hanousek \& Richard Podpiera, Information-Driven Trading at the Prague Stock Exchange: Evidence from Intra-Day Data, 10 ECON. TRANSITION 747 (2002); Richard Small, From Tatemae to Honne: A Historical Perspective on the Prohibition of Insider Trading in Japan, 2 WASH. U. GLOBAL STUD. L. REV. 313 (2003).

${ }^{32}$ There are a few exceptions, primarily academic, more notable as proof of the proposition in the text than for suggesting popular revulsion about the practice such as we find today. See BERLE \& MEANS, supra note 29 , at 223-26, 326 (condemning insider trading as an abuse of access to information in the official capacity and treating inside information as the collective property of the shareholders); FRANK P. SMITH, MANAGEMENT TRAding: STOCK-MARKETS PRICES AND PROFITS (1941) (applying economic analysis to trading by corporate insiders but ultimately condemning insider trading on nonpublic information); H.L. Wilgus, Purchase of Shares of Corporation by a Director from a Shareholder, 8 MicH. L. REV. 267, 297 (1910) (arguing that insider trading "does more to discourage legitimate investment in corporate shares than almost anything else"). More to the point, the Pujo Bill, a comprehensive federal securities statute proposed in 1913 after well-publicized congressional hearings, had a provision regulating trading by corporate officers and directors. H.R. REP. No. 62-1593, at 171-72 (1913). There were even business witnesses who criticized the practice of insider trading (but did not endorse the proposed regulatory measures) during the subsequent Senate hearings in 1914. See Regulation of the Stock Exchange: Hearings on S. 3895 Before the Senate Comm. on Banking and Currency, 63d Cong. 152-53, 267-68 (1914). But this was not the central theme of the hearings, and nothing came of the provision regulating insider trading. Again, the failure of any follow-up or of any increased concern after the hearings seems to strengthen the point that there was no serious public concern with insider trading prior to Texas Gulf Sulphur.

Perhaps the same can be said about the "minority" common law view that insider trading was improper (though no early case even involved an anonymous transaction on an exchange). See WANG \& STEINBERG, supra note 2, §16.2.3.2.

Admittedly, Section 16(b) of the Securities and Exchange Act of 1934 was sold to the public as an antiinsider trading provision, but its reach was so limited, that it was never thought of as a comprehensive effort 
mention it in polite company, as the words "cancer" or "incest" used to be treated. But there is little evidence that prior to the SEC's efforts in this regard, insider trading had anything like the connotation of extreme immorality implied by this theory. There is no evidence of any general revulsion by the business community or the public towards insider trading in those "good old days".

One might argue that the adoption of the securities laws of the New Deal, with their ostensible "full disclosure" philosophy, reflected a general dissatisfaction with the state of affairs in securities markets, including insider trading. But this would be a serious misreading of that history, since that legislation, like most other New Deal regulation, was aimed primarily at preventing or suppressing competition, regardless of what incidental rationalization may have been offered the public for political reason. ${ }^{33}$

And while it is true that there would have been considerable "free rider" problems if any one company had tried to enforce a rule against insider trading, again this would not explain the universal silence on the subject. Indeed, if this were part of the explanation, it is much more likely that we would have heard a public clamor for government assistance with the problem rather than total silence.

It might be argued that, while there was universal disapproval of insider trading, the managers, who were the chief perpetrators, would naturally keep silent about their transactions. This explanation would apply equally to all top managers, board members and controlling shareholders, and thus it could theoretically explain the universal silence on the subject. But this hypothesis is flawed. Top managers or controlling shareholders

to deal with the subject. Even so, the New York Stock Exchange sought repeal of that provision only a few years later. See supra note 30.

${ }^{33}$ See Ellis Hawley, The New Deal And the Problem of Monopoly (1966). Hawley found a real anticompetition motive but a different, publicly stated purpose, in connection with the creation of every New Deal agency except the SEC. The exception Hawley thought he found was clearly an error. See also Henry G. Manne, Economic Aspects of Required Disclosure under Federal Securities Laws, in WALL STREET IN TRANSITION: THE EMERGING SYSTEM AND ITS IMPACT ON THE ECONOMY 21, 31-36 (Henry G. Manne \& Ezra Solomon eds., 1974) (discussing possible anticompetitive motives and consequences of the federal securities laws); Henry G. Manne \& Joseph J. Bial, Questioning the SEC's Crusades, REGULATION, Winter 
could not have been the only individuals with access to undisclosed information, and they would have no reason to "cover up" the trading of others. Accountants would have valuable financial information before the CFO; salespeople and plant foremen would know of speed-ups in orders and production before the $\mathrm{COO}$; and outsiders would know of pending merger offers before the CEO. Even mid-level executives, to say nothing of secretaries, elevator operators, and office boys, would certainly on occasion have had access to tradable information. Anyone might indeed have had some reason to remain silent about his or her own trading, but that would not explain the silence of the top managers about underlings' trades.

Or consider the matter of trading on bad news by various employees of a company. One would expect top managers to scream like stuck pigs if underlings traded on information which the superiors did not yet have and which would lower stock price. Such behavior could jeopardize managers' own job security. It is conventional wisdom that top managers of publicly-held companies do everything they can to put a rosy hue on any public disclosures and even on the company's financial accounting. Clearly, their interest in survival, as affected by the impact of bad news on the share price, would prevail over any wish to hush up insider trading by others. Thus we could hardly expect that to explain their total silence on the subject, since, in this case, insider trading might be harmful to them.

But what if the top managers were making so much money from trading on undisclosed information themselves that they were willing to acquiesce in underlings' participation in order to avoid killing the gold-bearing goose? This too fails on close examination. Top managers may well have had access to some valuable information before its trading value was frittered away by underlings, but controlling shareholders who were not directly involved in the management of the company would not. If they were being cut out by their managers, there is no reason to believe that they would not complain about it or at

2001, at 8 (hypothesizing a restraint-of-competition motive behind the SEC's initial sally into the subject of insider trading in the 1960's). 
least cite it as a reason for putting in new managers. Of course, they too could all have been part of an enormous conspiracy of silence, ${ }^{34}$ but the odds are strongly against that.

So it is highly unlikely that corporate managers of the relevant period thought there was a problem with the practice at all. On the other hand, if some (net) advantage to the practice existed of which managers then were even dimly aware, then their silence might well imply approval of the practice. Recognition of some benefit to insider trading would still not necessarily result in public discussion of the topic. Silence might still follow because there was no market pressure, and no social, intellectual, or psychological incentive, to open the issue publicly. If any disadvantage from insider trading had been recognized by important business spokespersons of the day, silence would have been unlikely. Conversely silence could well have been the consequence of approval. ${ }^{35}$ Our remaining task then is to see if there was some benefit to the managerial function from insider trading other than the compensation argument which we have already discounted.

\section{PART III - THE MYSTERY SOLVED}

One possible solution to this query is suggested by a surprising source, Friedrich Hayek's classic The Use of Knowledge in Society. ${ }^{36}$ In that piece Hayek advances the notion that the most important task of an economic system is not the efficient allocation of goods and services. If the necessary knowledge of relative values were available, those calculations would not in theory be difficult. Though these observations are made in the context of a discussion of central economic planning, his language, as we shall see, seems equally applicable to some of the problems of managing a large corporate enterprise.

The real problem for the socialist planner, as Hayek identified it, is how to manage the necessary information in practice, since "the knowledge of circumstance ... never exists

\footnotetext{
${ }^{34}$ For the farfetched plea for regulating insider trading to prevent managers from using inside information to "bribe" dominant shareholders to refrain from monitoring (certainly a kind of conspiracy theory), see Ernst Maug, Insider Trading Legislation and Corporate Governance, 46 EUR. ECON. REV. 1569 (2002).

${ }^{35}$ We have already mentioned that it is highly unlikely that they were merely unaware of the practice or that they could not recognize either an advantage or disadvantage from it.
} 
in concentrated or integrated form, but solely as the dispersed bits of incomplete and frequently contradictory knowledge which all the separate individuals possess." ${ }^{37}$ Hayek's argument that "[t]he various ways in which the knowledge on which people base their plans is communicated to them is the crucial problem for any theory explaining the economic process ${ }^{\prime 38}$ applies equally well to the problem of managing a large corporation. In other words the essence of management is not the substance of the information needed for decisions but rather the process by which information which is somewhere "out there" gets communicated to the decision maker.

Hayek compared "central planning," which, "by its nature cannot take direct account of . . . circumstances of time and place" to "decentralized competition," in which the decisions are left to "the man on the spot." ${ }^{, 9}$ The parallels to the managerial problem are very suggestive even if not exact. Top-level managers are regularly beset with enormous problems of getting appropriate, truthful, and timely information for making decisions, ${ }^{40}$ decisions which in many particulars are similar to those a central economic planner would have to make. And, while the corporate manager, unlike the central planner, cannot leave decisions up to "the man on the spot," Hayek's euphemism for a market process, the manager may have access to a related type of information source unavailable to the socialist planner.

Information comes to top managers, of course, in many forms and through various devices. From within the company, the decision-makers might receive accounting and statistical data and written and oral reports from subordinates. From outside the company, the managers might enlist various kinds of consultants, auditors, or attorneys.

\footnotetext{
${ }^{36}$ F.A. Hayek, The Use of Knowledge in Society, 35 AM. ECON. REV. 519 (1945).

${ }^{37} I d$. at 519.

${ }^{38} I d$. at 520 . Hayek makes a distinction between scientific knowledge and the kind of knowledge of the "particular circumstances of time and place" which by its nature cannot enter into statistics such as a central planner would need, $i d$. at 524, or, it might be argued, into accounting data of the sort to which the SEC gives preeminence.

${ }^{39} I d$.

${ }^{40}$ For a brief summary of the types of information-transmission problems corporate managers confront, see Stephen M. Bainbridge, Privately Ordered Participatory Management: An Organizational Failures
} 
Information can also be gleaned from public disclosures, paid informants, or even books. But even assuming (a real stretch to be sure) the correctness and the relevance of all information obtained through these devices, one critical failing will be found in every one of them. Anything other than information based on first-hand experience (a very limited possibility) will necessarily be somewhat "stale." This is not to deemphasize the fact that much of the information will be erroneous, irrelevant, and/or biased. It is merely to point out that no matter how correct the substance of the information, it will always take time for it to reach the decision maker, a delay that in some cases can prove fatal. Information of this sort will always lack the immediacy of what Hayek referred to as "the knowledge of the particular circumstances of time and place." ${ }^{41}$

For Hayek, the solution in the case of economic organization was for diffused decision makers to utilize the market price of a commodity in their decisions, since that price contained significant information that diffused individual (private) planners need in order to make intelligent decisions. The price of a good or service or commodity was always immediately available and, as a guide to individual choice, inherently correct. ${ }^{42}$

But obviously the manager is not a central economic planner, and diffused competition is not usually a feasible alternative way to organize the administration of a single firm. Nonetheless, suggestive similarities remain. As Hayek showed, "The most significant fact about this system is the economy of knowledge with which it operates, or how little the individual participants need to know in order to be able to take the right action." ${ }^{43}$

Consider the plight of a top manager of a corporation considering the expansion of a major division of the company. He has probably received rosy reports about the

Analysis, 23 DEL. J. CORP. L. 979, 1013-14 (1998). But the "management" literature on the subject of information flows to decision-makers is enormous, clearly reflecting the seriousness of the problem.

${ }^{41}$ Hayek, supra note 36, at 524.

${ }^{42} I d$. at 526.

${ }^{43} I d$. at 526-27. "The marvel is that ... without an order being issued, without perhaps more than a handful of people knowing the cause, tens of thousands of people whose identity could not be ascertained by months or investigation, are made to use the material or its products more sparingly; i.e., they move in the right direction." Id. at 527. 
division's performance even though, perhaps contemporaneously, the price of the company's stock is in sharp decline. We will make the simplifying assumption that all other divisions are known to be steady and the general business conditions have not changed. ${ }^{44}$ Clearly that manager has some unbiased information that things are not all they appear in his reports to be, and prudence dictates finding out what is really wrong with that division before approving the expansion. ${ }^{45}$

A scenario like that would not be realistic unless someone with information more reliable than that given to the top executives was trading in the company's stock. The manager would not care who got that information or how that person procured it; he would not care whether the trader was an insider or an outsider. He would not care whether the person was a file clerk or an investment banker. What would be important is, first, to stop the planned expansion; second, to find out what was wrong with the division; third to fix the problem; and possibly a fourth, take steps to deal with the producers of the erroneous reports. Each of these represents an important managerial action, and each of them depends on the information first gained through watching the stock's price. ${ }^{46}$

Or consider a manager faced with a well-publicized acquisition decision and a stock price that has declined more than such an acquisition should occasion. He should recheck all the numbers and pause before completing the acquisition. Any other course threatens serious litigation, or worse, later on. The information being impacted into the share's price may have come from insiders or outsiders, but, in any event, someone is betting

\footnotetext{
${ }^{44}$ This example incidentally strongly supports the use of so-called "tracking" stocks to aid in corporate management. For an example of exactly this scenario, see Joel T. Harper \& Jeff Madura, Sources of Hidden Value and Risk Within Tracking Stock, Fin. MGMT., Autumn 2002, at 91. But the scenario, and the others following, is much closer to the ideas implicit in the modern theory of "prediction" markets, the creation of virtual markets in almost any kind of future state. The system has until recently been used primarily to make election outcome predictions, but it is increasingly finding a place in the corporate world. See infra notes 54-55.

${ }^{45}$ See James B. Kau et al., Do Managers Listen to the Market?, 14 J. Fin. InTERMEDIATION (forthcoming 2005) (offering empirical evidence that managers "listen to the market," as they are more likely to cancel investments or merger plans when the market reacts unfavorably to the related announcement).

${ }^{46}$ The prototypical New Yorker cartoon of a mogul watching the ticker tape in his office implied that he was "playing the market" on company time. But the grain of truth in the office presence of a ticker tape had to be that the top manager was watching primarily his own company's stock price.
} 
their own money on the validity of numbers quite different than those the executive has been given. ${ }^{47}$ There is great peril in ignoring such information. ${ }^{48}$

An additional scenario involves a situation that must be common in high-tech fields or others with rapidly changing technology. Suppose that a publicly traded company is riding high with a dominant product in its particular market but not a product that is fully protected by its patents against substitutes. Orders are high, earnings estimates are generous, morale among employees is good, consumer response is enthusiastic, and the managers are about to cash in on their stock options. Just then, for no reason known to the company's top management, the stock plummets. It is in fact being shorted ${ }^{49}$ by employees of another company which has developed a far superior substitute product. ${ }^{50}$

Or consider a case of substantial embezzlement and accounting fraud. Top managers notice an otherwise mysterious decline in stock price. This can set off alarms that ultimately lead to discovery of the fraud. But why did the stock price decline? Obviously someone in the know about the fraud decided that stock trading profits were better than the "honor" of whistle-blowing, and, at least this way, other employees of the company may never know who the "snitch" was, thus avoiding various personal embarrassment and recriminations. But why would the top managers care who did the trading or even

\footnotetext{
${ }^{47}$ Yuanzhi Luo, Do Insiders Learn from Outsiders? Evidence from Mergers and Acquisitions, 60 J. FIN. (forthcoming 2005) (offering empirical evidence that market reaction to an M\&A announcement predicts whether the companies later consummate the deal and that merging companies appear to extract information from the market reaction and later consider it in closing the deal).

${ }^{48}$ Or, it might be added, in not having it available because insider trading laws have prevented someone with the relevant information from trading or disseminating the information. But I digress; the point of the text is merely that the stock market may convey valuable managerial information either not available or not available in timely fashion anywhere else. A manager might be at some pains to preserve such a valuable source of information and, to repeat the point of the text, not be heard to complain that someone has "immorally" traded on inside information.

${ }^{49}$ The feasibility of short-selling and the existence of options or futures markets generally improve the process of aggregating information by allowing more individuals to profit on their information and making the market for the underlying security more "complete" and hence more efficient. See Stephen Figlewski \& Gwendolyn P. Webb, Options, Short Sales, and Market Completeness, 48 J. FIN. 761 (1993).

${ }^{50}$ While there is a great debate as to whether this trading would run afoul of Rule 10b-5 - it is not trading by an insider trading in the usual sense - this example nonetheless still serves to make the point about managers being dependent on stock prices for information they may be unable to secure elsewhere. See also Ian Ayres \& Joe Bankman, Substitutes for Insider Trading, 54 STAN. L. REV. 235 (2001).
} 
how those traders knew about the fraud? That knowledge would not be required (nor cheap to acquire) before the managers could take necessary corrective action.

This example suggests a more general use of stock price in the day-to-day work of top administrators. If the managers could assume that informed trading was taking place whenever it became profitable - in other words, if managers had acted as though the stock market were "efficient" long before the idea of an efficient market was articulated they could also have used stock price changes as a kind of confirmation, albeit "noisy," of their own internal financial and other reports. In other words, general insider trading would go a long way towards keeping various functionaries on their toes and honest, since every major error or act of dishonesty would become a potential source of trading profit for someone else in the organization who knew about the problem. ${ }^{51}$

That last idea in turn suggests yet another reason for silence about insider trading, this time by controlling shareholders. The problem of monitoring non-controlling managers was certainly recognized by investors and entrepreneurs long before Berle and Means popularized the notion of a separation of ownership and control. Manifestly, no agency relationship of this kind is feasible without some device for monitoring the quality of work done by the agents. Are large investors who do not directly manage their companies merely to wait until they receive obscure quarterly or annual financials before making decisions about the quality of their managers? And even if they serve or have representatives on the board, can they be assured of speedy and correct information about the real value of managerial decision making? This is the agency cost problem par

\footnotetext{
${ }^{51}$ It goes without saying that we are discussing those cases in which the trading is sufficient to move the price of the company's shares. This implicates the great debate about the effectiveness of insider trading to move share prices. The emerging consensus in the literature seems to be that this mechanism functions rapidly with few trades by insiders necessary to create a substantial movement in the indicated direction. See supra note 10. Probably this effect would vary with the size and liquidity of the market for the particular company's shares, the number of analysts following the shares, and other factors. But the fact that the scheme may not function well to solve every managerial information problem is clearly no reason for not allowing it generally for those situations in which it is useful.
} 
excellence, and a feasible solution is to allow, nay encourage, insider trading in order to assure as fast and accurate conveyance of information as possible via stock price. ${ }^{52}$

One would guess that these investors would want every bit of market price information they could possibly get, whether it came from stock trading by insiders or by the devil. With all the difficulties non-managing shareholders will have in securing adequate information to protect their investment, it certainly comes as no surprise to learn that large shareholders are rarely heard to complain about insider trading. What is more surprising is that they and others with concurrent interests did not mount a more successful effort to thwart the SEC's campaign against the practice. ${ }^{53}$

The various examples given above help explain why managers and others could have been expected to remain silent about insider trading in its heyday. But these same scenarios are also significant because today they could represent actual corporate experiments with so-called "virtual" or "prediction" markets. ${ }^{54}$ These schemes typically involve the use of an internally constructed mock or virtual stock market or derivatives markets to assess a specific population's valuation (prediction of success) of, for example, a new product or managerial decision. ${ }^{55}$ The practice is based on the Hayekian

\footnotetext{
52 This insight makes particularly ironic that Berle and Means complained that managers of large corporations might engage in insider trading. See also Kau, et al., supra note 45, at 33-34 (offering empirical evidence that "managers are more likely to listen to markets when a higher proportion of the firm's shares are held by blockholders").

${ }^{53}$ But see supra note 30 (showing some concern about Section 16(b)). It may well be the SEC's highhanded method of developing a general rule against insider trading did not allow for such public expression of concern after Cady, Roberts. Just to remind those who are unfamiliar with this history, the Cady, Roberts adjudication decision, interpreting Rule 10b-5, was published long after the decision as an administrative adjudication opinion. It was the farthest thing from a rule-making procedure, and most observers at the time did not even think that there was now a new rule. That doubt was not finally resolved until the Second Circuit accepted that reading of Rule 10b-5 in Texas Gulf Sulphur. See Henry G. Manne, Insider Trading and the Administrative Process, 35 GEO. WASH. L. REV. 473 (1967). The SEC may well have taken this approach because they did not want public comment in a rule-making proceeding, nor did they want to alert Congress to the radical law making they were engaged in. Given that reading of what occurred, it certainly is not surprising the business community, for the most part, simply let the "dictum" of Cady Roberts ride, at least until it was too late really to do anything about it.

${ }^{54}$ For an excellent description of internal markets for "securities" predicting future sales, success of a certain product, or supplier behavior in such companies as Eli Lilly, Hewlett-Packard, and Microsoft, see Barbara Kiviat, The End of Management?, Time (Inside Business Bonus Section), July 12, 2004.

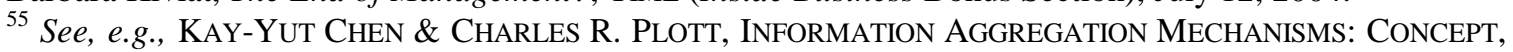
Design, and Implementation for a Sales Forecasting Problem (Cal. Inst. of Tech., Soc. Sci.
} 
idea that markets are better organizers of information and predictors of the future than are individuals.

Prediction markets in the corporate world are designed to mimic as nearly as possible the conditions of a real market. Thus they work more effectively if the individuals betting use their own money and trade to make more money, just as in real markets. The idea is that people with the greatest confidence in the validity of their information will bet more on that supposition than will those who lack such confidence, and the aggregate betting will produce a "price" outcome much more accurate than any one individual could produce, just as Hayek suggested. ${ }^{56}$ There are problems with getting the incentive structure right in virtual markets, problems that do not exist in real markets, but the results to date are nonetheless dramatically persuasive of the valuative and predictive powers of such markets. ${ }^{57}$

The similarities and overlaps between the Hayekian "use of knowledge," virtual markets, and insider trading should now be apparent to anyone. They each involve, actually or virtually, one and the same thing, namely a market for information. And this market inevitably performs far more successfully than would most any non-market administrative process, whether the latter be socialist central planning, marketing surveys by polls, or

Working Paper No. 1131, 2002). The paper discusses, among other issues, the question of whether the prediction-market mechanism can identify knowledgeable individuals and provide an incentive for them to participate, $i d$. at 8-9, a problem which does not exist in a real legal market for inside information. See also AJIT KAMbril \& ERIC VAN HeCK, MaKing MARKETS: How Firms CAN DESIGN AND PROFIT FROM ONLINE AUCTIONS AND EXCHANGES 149-155, 159-61 (2002) (discussing how prediction markets can aid corporate decision-making); Justin Wolfers \& Eric Zitzewitz, Prediction Markets, J. ECON. PERSP., Spring 2004, at 107 (summarizing academic literature on prediction markets).

${ }^{56}$ See also JAMES SUROWEICKI, THE WISDOM OF CROWDS 23-39 (2004) (emphasizing the importance of diversity of beliefs among the participants in a virtual or a real market for the "magic" of the aggregation of disparate valuations to work). This is another reason why the exclusion of insiders from the stock market guarantees a less efficient market than would exist otherwise.

${ }^{57}$ Readers are most apt to be familiar with the Iowa Electronic Markets for betting on political campaigns. These have proved to be considerably more successful than any polling device for predicting the outcomes of American elections. See Iowa Electronic Market Website, at http://www.biz.uiowa/iem (last visited

). The use of prediction markets made headlines a few years ago when the Department of Defense DARPA office tried to use a virtual market to predict terrorist activities. A popular outcry that this allowed "betting" on terrorism and carried moral hazards forced DOD to cancel the project. See Robin Hanson \& Ryan Oprea, Manipulators Increase Information Market Accuracy 2 \& n.2 (July 2004) (unpublished manuscript, on file with author), available at http://hanson.gmu.edu/biashelp.pdf (last visited 
mandated financial disclosures such as required by the SEC. Certainly it should be clear now why corporate managers and others with a real interest in managerial efficiency would not have complained about insider trading when it was widely recognized as a standard practice. Their jobs were - and still are - much simplified with a free and open information market for all possible participants. ${ }^{58}$ There never was any need, therefore, to include insider trading in executive compensation packages. ${ }^{59}$ Even in this day of regulated, distorted, and corrupted information flows, the smart managers must still keep a weather eye out for unexpected changes in their company's stock price. ${ }^{60}$

The illustrations used above are considerably oversimplified and describe a kind of event that does not occur every day. In fact, the truly dramatic case of important information being conveyed almost instantaneously by the stock price may be one of the rarer events in a top manager's career. Even so, there would not have to be many such occasions, experienced directly or only heard about, before managers would understand the desirability of having insider-trading influenced stock prices available. So managers, directors, and large shareholders may have had little or no incentive ever to talk about insider trading as an important managerial tool and certainly none to condemn it. A culture of silence on the subject seems the most likely result. The mystery posed earlier

\footnotetext{
${ }^{58}$ So much for the argument that it would be "unfair" if an office boy, a janitor, or a secretary were allowed to trade on information that was fortuitously picked up while on the job. Cf. United States v. O'Hagan, 521 U.S. 642 (1997) (holding liable a law firm partner not personally representing the company whose options and shares he traded). Management's interest would be just as great in having these low functionaries trade on new information as the highest level executive, so long as their trading added to the accuracy of the stock's price. It's reliable price-effect information they are after, not some puerile ideal of "fairness." This is not to say, of course, that there may not be situations in which it will be in a company's interest to delay information reaching the market, say where this would be valuable mainly to competitors. In such a case, however, we could expect the managers to take whatever steps were appropriate to guard the information and not to rely on a general rule against insider trading to cure a rarely occurring problem.

${ }^{59}$ This is not to say, however, that there may not have been special cases where inventors or other entrepreneurs were explicitly allowed, as part of their compensation package, to trade on the value of the information they produced. This might have been especially appropriate to cover such cases as pharmaceutical scientists working on new drug products and betting on their success. A company could then get the advantages of a prediction market with the additional advantages of an appropriate form of incentive compensation. This is not the same as a generalized argument for insider trading as part of all compensation packages, which, as we have seen, entails considerable operational problems.

${ }^{60}$ It is an open question just how much SEC regulation has distorted the market for valuable information, and the matter has not been addressed by empirical research. Still, we do know that enforcement of insider trading laws is spotty and ineffective, but whether it is ineffective enough that we still have substantially as
} 
in this paper has now been solved, and a new defense of insider trading has been described.

\section{PART IV - THE WRAPUP}

There are arguments against this new hypothesis in support of legalized insider trading. First, there is the practical point that the stock market is notoriously volatile, and a manager may be hard pressed at any give moment to know whether the stock price change he is witnessing is a result of informed trading or of so-called "noise" trading. ${ }^{61}$ "Noise" will significantly complicate the task of ferreting valuable insights out of a stock's price, and on occasion noise might make it impossible to infer any valuable information from a stock price. But the ability to analyze stock price changes should probably be seen as another desirable skill for managers. The fact that noise may create some uncertainty with this kind of information and on occasion may make it useless certainly does not imply that this information should never be available to managers as well-enforced insider trading laws in effect would do.

A related point is that stock markets are always subject to manipulation and that managers relying on stock price to gain new information will regularly be "confused" by others trying to convey false information. ${ }^{62}$ While this observation seems plausible, it fails to note that alternative schemes of transmitting information are equally if not more subject to the same risks. Even more to the point, however, this argument does not integrate the possibility of "counter manipulators," who can profit by trading on the truth

reliable and accurate a market for information (net of all the administrative costs of the system) as we would in the absence of the regulation is anyone's guess.

${ }^{61}$ Aggregate market or industry price movements would not obviously have the same value since a general price level change would not implicate the kind of information we are concerned with here.

62 For some suggestion of this kind, see Saul Levmore, Simply Efficient Markets and the Role of Regulation: Lessons from the Iowa Electronic Markets and the Hollywood Stock Exchange, 28 J. CORP. L 589, 600 \& nn.36-37 (2003). Actually Levmore, in a somewhat different context, skirts near to ideas proposed in this paper, but he seems reluctant to acknowledge any valuable role for insider trading. Id. at 588-89. For important studies of the problem of manipulation, see Robin Hanson et al., Information Aggregation and Manipulation in an Experimental Market, 56 J. ECON. BEHAV. \& ORG. (forthcoming 2005); Robin Hanson, Foul Play in Information Markets (Jan. 2005) (unpublished manuscript, on file with author), available at http://hanson.gmu.edu/foulplay.pdf (last visited 
regardless of what their colleagues are up to. All indications are that significant stock price manipulation is extremely difficult to manage, and, ironically, it may actually improve the functioning of the market. ${ }^{63}$ This is similar to the point made earlier about the value of insider trading on bad news. In both cases allowing an unfettered market in information will have salutary effects unheard of in connection with regulatory "disclosure."

There is a special advantage that virtual markets have over real markets powered by informed trading. They can be carefully tailored to a very specific query such as "how will a particular new product fare in the market?" A generalized market for all information, like the stock market, cannot normally perform with this degree of specificity, but on occasion its message will be specific and clear. The fact that this is not always the case is simply one of the conditions of the marketplace; it is not a drawback to insider trading as such.

Of course, since the argument for allowing insider trading presented here is brand new and largely theoretical, we have little direct empirical or even anecdotal evidence to support it. However, we do have a rapidly growing number of reports of experimental work in prediction markets, none of which, needless to say, involve actual trading of stocks on a stock exchange. And a number of new questions for exploration come to mind. Do managers follow their company's stock price with an obsession suggesting that it contains really valuable information for them (above and beyond their own direct interest in stock-price-related compensation plans)? Do we have any evidence that problems have actually been discovered through this mechanism? Are there other factors that would make stock price monitoring a losing proposition, such as noise, unreliable data, more efficient alternative information-transfer devices, or excessive time or other costs associated with the practice?

\footnotetext{
${ }^{63}$ See especially Hanson \& Oprea, supra note 57. Levmore also notes that profits can be made by counter manipulators and that ultimately an equilibrium may develop. Levmore, supra note 62, at 601.
} 
Even after the SEC began its in terrorem campaign against insider trading and required compliance officers nearly everywhere, few top executives of large corporations have made ferreting out insider trading a top priority of their administrations. In other words, though the silence on the topic has not been as complete as it was before Texas Gulf Sulphur, complaints about the practice have still not been deafening. Most of the roar comes from the SEC and its supporters in the academic and media worlds. So, we might wonder, does this signify acquiescence by the corporate elite in the SEC's campaign against insider trading or does it merely mean that the campaign has been mainly bluster and headlines with an extraordinarily low enforcement capability? ${ }^{64}$

All of these are interesting questions that may be asked about the Hayekian hypothesis for insider trading. Possibly a new area of scholarly research has been opened. The hypothesis seems to have enough "bite" that it will have to be integrated into the general argument about insider trading that continues to rage. If the issue were a close one before this notion appeared, this could tip the balance, and we may even begin to see some advocacy of insider trading legality from those whose interest, professional or academic, is in making the management of large companies more efficient.

\section{PART V - CONCLUSION}

Stock trading by any informed individuals can produce information that may be extremely valuable to managers of publicly-held companies. This may result in benefits that are even greater than those that were claimed for insider trading as a device to make the stock market more efficient. That older argument related efficiency of capital markets almost entirely to activities stock-market activities such as investing, stock trading, or

\footnotetext{
${ }^{64}$ Ajeyo Banerjee \& E. Woodrow Eckard, Why Regulate Insider Trading? Evidence from the First Great Merger Wave (1897-1903), 91 AM. ECON. REV. 1329 (2001); Michael P. Dooley, Enforcement of Insider Trading Restrictions, 66 VA. L. REV. 1 (1980); Javier Estrada \& J. Ignacio Peña, Empirical Evidence on the Impact of European Insider Trading Regulation, 20 STUD. ECON. \& FIN. 12 (2002); David Hillier \& Andrew P. Marshall, Are Trading Bans Effective? Exchange Regulation and Corporate Insider Transactions around Earnings Announcements, 8 J. CoRP. FIN. 393 (2002); Jeffrey F. Jaffe, The Effect of Regulation Changes on Insider Trading, J. Bell J. ECON. \& MGMT. SCI. 93 (1974) H. Nejat Seyhun, The Effectiveness of Insider Trading Sanctions, 35 J.L. \& ECON. 149 (1992); Arturo Bris, Do Insider Trading Laws Work? (Feb. 2003) (unpublished manuscript, on file with author).
} 
transactions in control. ${ }^{65}$ Now we have added a corporate-governance dimension to the insider trading debate. Indeed when we view the topic in Hayekian terms, it is hard to escape the conclusion that knowledgeable trading in an earlier era did and probably still does aid considerably in the functioning of the large corporate system. And a new question arises whether virtual markets can provide a meaningful alternative to overt legal insider trading, if indeed regulation of that trading has even significantly reduced its informational benefit.

There is a lot of evidence that insider trading simply went underground ${ }^{66}$ and that no substitute is really needed. SEC enforcement of its rules is a mess. It is arbitrary, capricious, political, and extremely inefficient. Nonetheless illegal insider trading, no matter how robust, is bound to be more expensive and less efficient than the legalized variety, and so it is not surprising that other devices might arise for surmounting the SEC's effort to hold back this tide. If the actual stock market cannot be used to gain certain information because of insider trading restrictions, then managers (though, alas, not outside investors) can create a virtual market to provide some of the same information. Virtual markets even have some benefits lacking in the actual stock market, such as the ability to segregate out specific causes of share-price changes. But virtual markets can never be a complete substitute because of the design and motivational problems mentioned earlier. But they can ameliorate some of the costs of the SEC's campaign against insider trading, and we can expect them to flourish. ${ }^{67}$

\footnotetext{
${ }^{65}$ However, the efficient market concept also has some relevance for the executive compensation debate. See Carlton and Fischel, supra note 14.

${ }^{66}$ See supra note 64.

${ }^{67}$ At least until the SEC decides that a virtual market operated with real money is close enough to the real thing to merit regulation. For some possible foretaste of this, see SEC v. SG, Ltd., 265 F.3d 42 (1st Cir. 2001) (ruling that trading in shares of "fantasy" companies on the Internet - perhaps easily distinguished from a prediction market - is still covered by the federal securities laws).
} 